\title{
THE POSITION OF PREHISTORIC RESEARCH IN ENGLAND
}

\author{
By J. REID MOIR, F.R.A.I. \\ Read in London, March 13 th, I9I7.
}

The present position of the science of prehistoric research in England cannot be said to be satisfactory. New and important discoveries are continually being made, and for some years past there has been a marked awakening of interest in this highly important subject. But this rejuvenescence has been accompanied by endless dissensions and disputations amongst archaeologists, and though by the fire of controversy truth is revealed, yet a dispassionate observer would marvel at the utter divergence of the views expressed, and conclude that the foundations upon which prehistorians wish to build are in a very shaky and unsound condition. And in the opinion of the author the dispassionate observer would be right. It would be regarded by any ordinary person as unthinkable that an engineer, for instance, should be unfamiliar with the exact nature of the materials with which he works, and the manner in which these materials fracture. One can imagine the great divergence of opinion which would be shown at meetings of engineering socièties were such ignorance of fundamental facts present. And what is true of engineering is true equally of all real science. Now what is the position regarding flint, which is the raw material of most prehistorical research?

Is it known exactly of what flint is composed, how it was formed, and in what manner, under various circumstances, it will break? Unfortunately the answer to these questions must be in the negative. We have the haziest notion of what flint really is, we do not exactly know how it was formed, and though the main characteristics of percussion, pressure and thermal fracture are known, the whole problem of flint fracture is by no means solved. Though the ordinary archæologist cannot be expected to be able to analyse flint or to give an authoritative opinion on the manner of its formation, yet it is the bounden duty of prehistorians never to rest until by hook or by crook such new knowledge is gained. He must either educate himself so as to be able to perform the task, or to persistently enlist the services of others, who are experts in the subjects involved in the questions at issue.

But as regards flint fracture there is no excuse for ignorance on the part of any prehistorians. Any one can fracture flints in various ways and take note of the results achieved, and in the opinion of the author no one who has not so fractured flint is in spirit and in truth a serious student of prehistory. We ought to know, and we must know, the exact differences, if such differences exist, between the 
fractures produced on the one hand by the unguided forces of nature, and on the other by intelligent human blows, and it is a disgrace to the science of prehistory that such knowledge is not already pos sessed. For many years past flint implements have been collected and elaborate theories of various kinds built up on the collections which have been made. These theories are in many cases probably sound, but on what sort of foundation do they rest ? The idea of the human fashioning of the first discovered neoliths was rejected, and later on the palæoliths were strenuously objected to and classed as naturally broken flints. But by degrees what is known as " common sense" prevailed, and it was recognised that these neolithic and palæolithic flints assumed definite forms again and again repeated, and that the flaking which had produced these forms was of a regular and peculiar nature, and not readily associated with fortuitous percussion, etc. And there were no doubt other reasons found for accepting the neoliths and palæoliths as being humanly fashioned. But there never were and are not now, any really satisfactory scientific reasons adduced for the acceptance of these specimens. The form of any flaked flint counts for nothing, it is the characteristics of the flaking which go to make that form which are of any real value. It may seem strange reading to many archæologists, but it is nevertheless a fact that no really satisfactory scientific data are at present available to make the acceptance of neoliths and palæoliths, as undoubted works of man, a certainty. And until it is known, absolutely and finally, what are the exact differences, if any, between human and natural flaking, the necessary data will not be available. If such data had been available what rapid progress would have been made in prehistory! The long years of wrangling about the neoliths, the persecution of $\mathrm{M}$. Boucher de Perthes, the discoverer of the palæoliths, and the acrimonious disputes as to the humanity of the more ancient pre-palæoliths would never have occurred, or if begun would have been of a less prolonged and heated character.

It seems, then, that it is the urgent duty of all prehistorians to work unceasingly to gain a real and thorough-going knowledge of fint fracture, so that these hampering and unscientific disputations may be eliminated from our study. At present the acceptance or rejection of any given series of flaked flints as being humanly fashioned, depends almost entirely upon the particular investigator's " temperament." If he is one who finds pleasure in thinking that the human race is of very great antiquity, he regards the flints favourably: if on the other hand he holds conservative views on the question of the antiquity of man, he regards them with disfavour. Such a position of affairs is the very antithesis of science, and at all costs must be ended.

Let us first consider the question of the most primitive edgeflaked flints of the "pre-palæolithic" series, such as were first discovered many years ago by Mr. Benjamin Harrison in the high-level plateau drift of Kent. These specimens were first known as " eoliths," but this term has unfortunately been misused by some 
archæologists, and has now lost caste amongst those who are anxious for the use of a precise nomenclature in pre-history.

The disputes and disagreements which have raged round the primitive Kentian plateau flints have been, and still are, of a very violent nature. Even though Mr. Benjamin Harrison enlisted the support of such a well-known and careful observer as the late Sir Joseph Prestwich, he has been unable to gain universal acceptance of his views. His supporters have stated that these Kentian flaked flints represent the earliest endeavours of man in shaping flint to his needs, and are exactly the type of specimen they would expect to find in deposits of the antiquity of those forming the high-level plateau drift of Kent. Other and more venturesome believers in the eoliths have professed to see in them various forms which in their opinion were used for cleaning the body and removing various callosities, such as apparently are the inevitable outcome of a free and healthy savage existence. Mr. Benjamin Harrison's opponents on the other hand cannot see in these flaked stones anything implemental, and they presumably do not believe that any members of the human race were ever so primitive as to use such specimens for removing callosities or for any other purpose. But they think it is certain that the flaking on the edges of the flints has been produced by various natural forces, and what is known as " earth creep," "foundering" and " torrential stream-action," are lightheartedly put forward as the most likely agents of fracture of the specimens. All of which is very unfortunate and unscientific and provocative of unending and profitless discussions. Surely it is of importance to prehistory to have this question of the human or natural origin of the primitive Kentian flints settled once and for all.* Every serious prehistorian will agree that such a final decision is urgently needed, and in consequence commence experimenting in flint fracture, and do his part in the elucidation of the problem. And what is true of the primitive Kentian flints is true also of the other series of pre-palæolithic specimens which have been discovered in various parts of this country. If it turns out eventually that these flaked flints are of human origin, then it appears we have in England a complete history of man's progress from the most primitive condition to his present high state of advancement. To be able to demonstrate scientifically the reality of such a progress would be a very great achievement, and one which ought to incite prehistorians to give their best in arriving at a final and satisfactory conclusion as to whether flints upon which the idea of this progress is based, are humanly chipped or not. And it must be remembered that only by gaining a real knowledge of the fracture of flint can such a result be attained. It may be thought by some that the discovery of human bones in association with pre-palæolithic flaked flints, and in an undisturbed geological deposit (such as occurred at Piltdown in Sussex), necessarily means that such flints are humanly fractured. But while it is true that such an associa-

\footnotetext{
* For a critical description of these Kentian flints see "Science Progress,"
} No. 43, Jan., 1917, pp. 431-440. 
tion affords strong presumptive evidence of the human origin of the flaking on the flints, it by no means proves it. The question of flint flaking must stand solely on its own merits, and cannot be influenced by any associated remains or relics of any sort or kind.

It will be seen from the foregoing remarks that the foundations upon which the edifice of prehistory has been erected, are by no means sound and satisfactory, and from our earliest days we have been familiar with the fate of houses built upon unsafe foundations. But it is not only the question of the "humanity" or otherwise of various flaked flints which has disturbed the archæological world. There are other and great differences of opinion. It has generally been held that all undoubted palæolithic implements are only found in deposits later in date than the glacial (chalky) boulder clay. This view was put forward very ably many years ago by certain eminent and careful geologists and archæologists, and is still very widely held. But of late certain investigators have registered their opposition to this long held belief. It has been stated that some of the earlier palæoliths are of early Pleistocene date, and, therefore, older than the boulder clay, while one well-known geologist has even gone so far as to declare that all palæolithic implements including some of the late "cave" forms, pre-date this glacial deposit.* Now the author confesses that he is inclined to favour the view that some of the earlier palæolithic implements are more ancient than the chalky boulder clay, because of the apparently close relationship between some of the flaked flints found beneath the Pliocene and pre-glacial Red Crag, and some of the earliest palæoliths.

But he nevertheless realises that so far as direct evidence is available, those who hold the opinion that all the palæoliths are post-boulder clay have much the stronger case. For it is a fact that up to the present in this country no definite, undoubted palæolithic implement has ever been found either in or beneath a stratum of typical undisturbed boulder clay. The author has himself searched extensively, and over a long period of time, the glacial deposits of Suffolk and elsewhere in the hope of finding a palæolithic implement in these beds, but with the exception of the finding of some palaeolithic-looking flakes, it has been an unavailing search. And it must be remembered that while papers written in favour of the pre-glacial age of some or all of the palæoliths are interesting and suggestive, yet until, if ever, a palæolithic implement is found either in or below a bed of typical, undisturbed chalky boulder clay, such papers must be regarded as purely theoretical.

Another matter which is at present grievously disturbing the archæological world is the question of the age of certain flint implements found upon the surface of the ground, or in superficial floors, etc., beneath that land surface. It has been the custom to regard all or most surface implements as of neolithic age, but this,

* Kennard (A. S.) : “ The Pleistocene Succession in England." Proc. Prehistoric Soc. of East Anglia, 1915-16, Vol. II., Part 2, 
on the face of it, is not necessarily a correct view. A flint implement lying upon the present land surface may be of any pre-historic human period. Deposits of palæolithic age may and do, in places, form the present land surface, and the humanly flaked flints from these deposits may be lying cheek by jowl with implements of a much later neolithic date. It is quite possible, also, that the associated palæolithic and neolithic flints may exhibit a similar patination and condition of surface. And this might lead some prehistorians to claim that the two series of implements were of the same age. But patination is a very unreliable and uncertain guide in such matters. Unfortunately we do not, at present, know what is the cause or causes of the patination of flint. Certain investigations have been made which have demonstrated that patination on flints can be produced artificially, and that various substances are capable of producing it. But we do not know how nature accomplishes this change in the surface of flint, though it seems very probable that she, too, has more than one agent of patination in her service. The problem will only be solved by careful, and probably prolonged experiments conducted by expert chemists and physicists, and it is to be hoped that such an investigation may be one day carried out. But there is no reason why a polished neolithic axe and a palæolithic implement should not lie side by side upon the surface of the ground, and show an exactly similar patination. Nor is there any reason for regarding patination of a flint implement as necessarily indicative of its age.

The palæolithic flints from the cavern of Le Moustier are almost all unpatinated, while those of known later date have suffered extensive surface change. In the excavations carried out at the flint mines at Grime's Graves by the "Prehistoric Society of East Anglia "it was found that the flakes nearest the surface of the ground and presumably the latest in date, at the sites where the prehistoric workers had made their implements, were patinated white, while those at the bottom of the mass of broken flints and presumably the oldest were quite black and unchanged. The patination of flint appears to depend solely upon the position and surroundings of the specimen, and if a palæolithic implement susceptible to patination is subjected to the same conditions as a neolith likewise susceptible to patination, there appears to be no reason of any sort why both should not assume an exactly similar colour and appearance.

It seems then that to claim on the grounds of similarity of patination that all implements found upon the surface of the ground are necessarily of neolithic date is unreasonable and illogical. But when the question of the patination of flint is disposed of, the forms of the implements are then brought forward as evidence. It is pointed out by some investigators that a series of implements from the shafts in the chalk, or the floors at Grime's Graves, or Cissbury (no floors have yet been recorded at this latter place), or from the surface of the ground, exhibit forms hitherto found only in deposits of Moustier, Aurignac, Solutré or Madeleine age, as the 
case may be, and that such a series of implements must be referable to the particular palæolithic epoch when similar forms were in vogue. It is pointed out also, and with truth, that up to the present we have no evidence that at any period, implements, say of Moustier and Solutré type, were contemporaneous.

The argument is carried further, and attention is drawn to the fact that in the caves of South Wales, Derbyshire and at Torquay it is evident that late palæolithic man had a habitat in this country, and it is pertinently asked how he got from the continent of Europe to these caves. The only reasonable presumption is that he progressed slowly over most of the south and south-east of England, and that when he found a cave he inhabited it, on the other hand when he did not, he encamped in the open country. All this is pointed out, and it is suggested that as no great geological changes and depositions have taken place since the later palæolithic men existed, it is quite in order to find their implements of flint either scattered upon the present land surface or buried in superficial "floors," or occupation-levels beneath it. Attention is also drawn to the fact that if the implements which are found upon the surface of the ground and in the various floors already mentioned, and which bear such a striking resemblance to the well-known late palæolithic implements of the French and Belgian caves, are neolithic, then we must alter completely our views as to the duration and character of the neolithic period. And we must also admit that there was a remarkable and hitherto unrecognised recrudescence of palæolith-like implements in neolithic times. But so deep rooted is the idea that surface implements and superficial floors are of neolithic date, that these views, though apparently reasonable, are not accepted, and the discussions over these unfortunate relics of ancient man wax fast and furious. It is true that there are various objections to the view that many of these surface implements and superficial floors are of palæolithic date. In some of the floors and at Grime's Graves, fragments of very rough and primitive pottery have been found, and most archæologists are not prepared to admit that pottery was made in palæolithic times. But pottery fragments have been found in various continental caverns, associated with an extinct fauna and late palæolithic implements.* English archæologists, however, are not at present very familiar with these superficial floors, etc., and in the past, if any have been discovered, they have probably, because of their nearness to the surface, been regarded as of neolithic date, and no further notice of them has been taken. It has been the custom when wishing to find palæolithic implements to visit sections in the main drainage valleys, and as such visits have generally been successful, it has come to be regarded almost as an axiom that palæolithic implements occur only in such valleys. But the main valleys are simply

* Rutot, Bull., Soc, Préhist. de France, 1907-8 (two papers). Annual Report Smithsonian Institution, 1913, p. 522. Römer: "The Bone Caves of Ojcow," London, Longmans, Green \& Co., 1884. Keith : "Ancient types of Man," 1911 , p. 111 . 
the depository of material from the adjacent high ground and tributary valleys which has been washed down in time of flood, and is now represented by deposits of gravel, etc., in the main valley. There is no doubt that such deposits are very rich in flint implements; that is inevitable, and from a mere collector's point of view nothing more is required. But it is not in gravels, etc., that we shall find out most about the manner of life of the people who made the flint implements found in such deposits. We must search for the remains of the floors from which these implements were originally derived, if we are to get to know more about the palæolithic races. Mr. Worthington G. Smith in his well-known book, "Man the Primæval Savage," in which he describes the Moustier floors of Caddington, etc., shows very clearly the truth of the foregoing statement. It is, perhaps, too much to hope that " floors" of early palæolithic date will ever be found, because being so ancient they have no doubt all been denuded, but there seems no reason why some of the later palæolithic floors should not exist, and it is the author's belief based upon much excavation that such floors do exist in some abundance, and especially in tributary valleys. Now let us suppose that a floor, for example, of Aurignac age, and in which occurs fragments of pottery and other fragile works of man, is washed away, and its contents swept down into the main valley and incorporated with a deposit of gravel. By the time the contents of the floor reached their destination in the main valley, the fragile objects mentioned would have been smashed up, and have disappeared, and only the resistant flint implements would survive the journey. It will thus be seen that the implementiferous deposits in the main valleys may give us but a very incomplete picture of the real life and capabilities of the various ancient races of men whose flint implements are found in those valleys.

Then again gravel no doubt accumulated rapidly to a considerable depth, and it may be that a late palæolithic implement, lying upon a floor in a tributary valley, and only a few feet from the surface of the ground, is of the same age as another embedded deep in gravel in the main valley. And whereas the floor specimen will be sharp and unabraded and probably unpatinated, the gravel implement will probably be rolled and abraded and exhibit considerable patination and staining. The author has in mind a case in his own district, of which he hopes to publish details in due course, which seems to support entirely the foregoing hypothesis.

There seems little reason to doubt that many isolated " floors," etc., have escaped denudation, and remained practically unaffected while geological changes of no mean order have occurred elsewhere. But in addition to the occurrence of fragments of pottery in these superficial floors, they are sometimes found to contain the bones of animals which have hitherto been regarded as of the "domestic" order and of neolithic date. And this brings up a very important question in palæontology.

This question the author does not feel able to discuss with very much profit as he is not a palæontologist. But he has read 
carefully a number of works dealing with this subject, and is inclined to think that the necessity for extinct or migrated animals, etc., to be in association with palæolithic implements before such implements can be stated definitely to be palæolithic, is somewhat of an obsession and rather overdone.* The future, however, will no doubt show whether this conclusion is correct or otherwise. But are there no other means of arriving at a decision as to whether the implements found in these superficial floors, and on the present land surface, are of a palæolithic date? The author thinks that there are, and here again he has a bone to pick with prehistorians. The fact is we ought to know exactly how the various palæolithic implements were made, and be able to say with certainty whether any given implement is referable to the Chelles, St. Acheul, Moustier, Aurignac, Solutré or Madeleine period.

But to acquire such a knowledge a prolonged and laborious research will be required.

It will be necessary to make accurate "flaking-diagrams" of large numbers of each type of implement, and to attempt to ascertain whether the maker of a Chelles implement for instance always proceeded on a definite plan. And the same idea would have to be applied to the St. Acheul, Moustier, Aurignac, Solutré and Madeleine specimens. The method of making a "flaking diagram" of a flint implement is as follows. The flint is first outlined, and the flake areas marked in with great care. When this is done each flake area must be carefully examined to see in which direction the blow was struck which detached the flake, and this can be done by observing the manner in which the conchoidal rippling curves, and the direction of the fissures which result from the blow. This being accomplished the direction in which the various blows fell can be indicated on each flake-area by means of arrows. The author has already shown in a paper read before the "Prehistoric Society of East Anglia" ("The natural fracture of flint and its bearing upon rudimentary flint implements ") and published in the first volume of their Proceedings, how it is possible to determine the direction in which the blow fell which detached any given flake. Two illustrations of flaking diagrams are given with this paper. (Fig. 77) a St. Acheul ovate implement, and (Fig. 78 ) a Moustier point. The letter T in the illustrations indicates that the flake is truncated, and such an indication would have to appear on all such flake areas in the drawings.

Having completed the flaking diagram as described an excellent idea can be obtained as to the manner in which the implement was made.

The flake-areas marked with an asterisk in the drawings represent the primary flakes which were detached in the original roughing out of the implement, and these are naturally very much truncated by the secondary flaking. This secondary flaking is indicated

* An illuminating article bearing somewhat upon this question, though not touching upon flint implements, will be found in Huxley's "Lay Sermons," pp. $176-197$. 


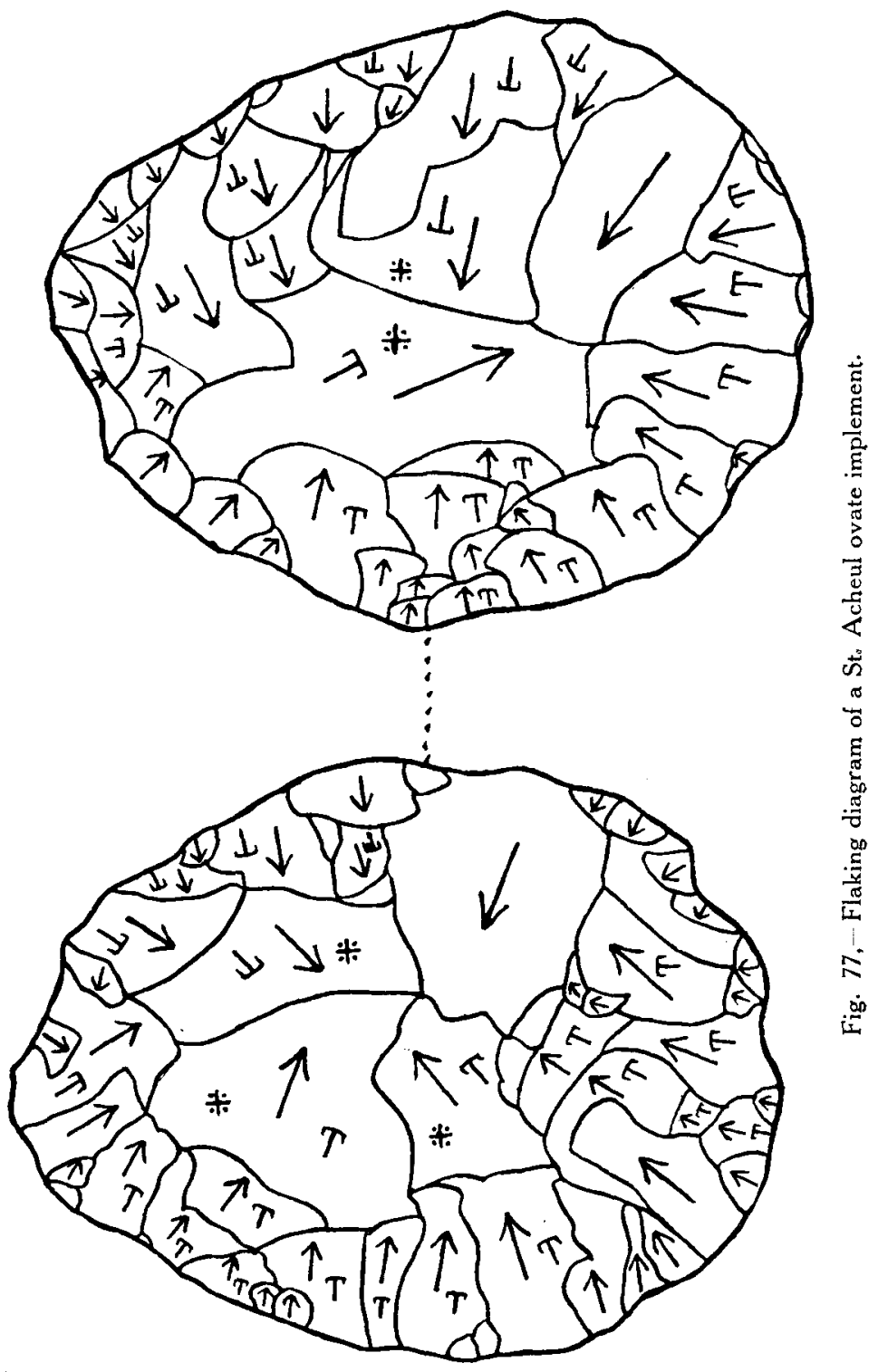


in the drawings by the flake areas not marked with asterisks. The letter $T$ indicates that the flake upon which it appears is truncated, those not exhibiting this letter are not truncated and exhibit the "negative-bulb" (in reality a hollow) of percussion. It will, of course, be recognised that the two implements illustrated (the illustrations, though based upon the form of two actual implements are for purposes of clearness slightly "idealised ") have been made in two quite different ways. The St. Acheul ovate (Fig. 77) was formed in all probability from an actual nodule of flint from which all the cortex was gradually removed by flaking. The Moustier point (Fig. 78) on the other hand has been made from a "dressed" block of flint from which a flake has been struck. One face is quite plain, and represents the fracture surface produced when the

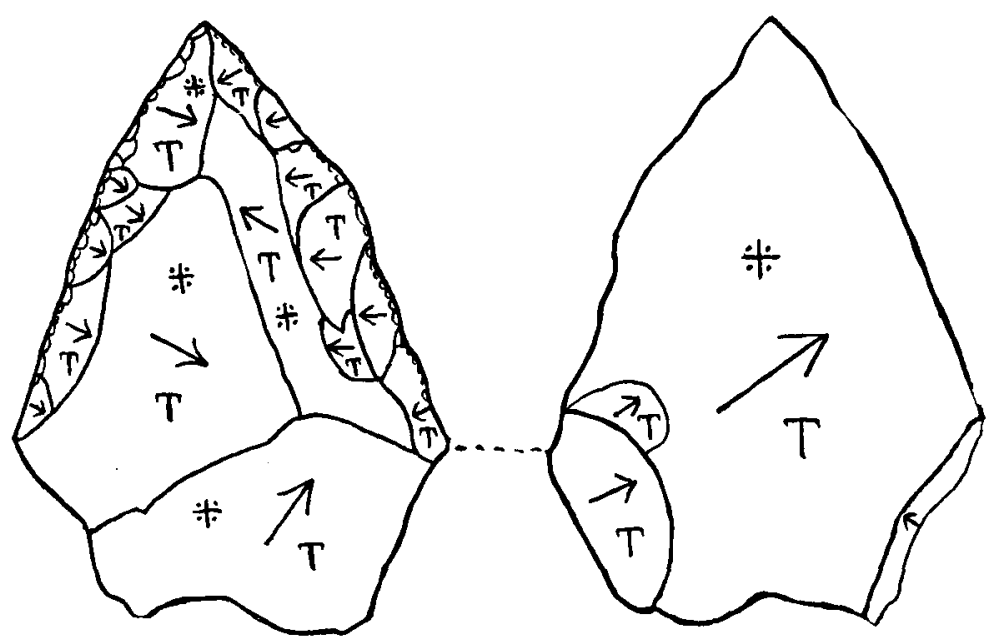

Fig. 78.-Flaking diagram of a Moustier point.

flake was removed from the parent block. If it were possible, and it ought to be possible, to get a large series of carefully executed flaking diagrams, on the lines of those illustrated, of implements of the Chelles, St. Acheul, Moustier, Aurignac, Solutré, and Madeleine periods, we might be able to see exactly how each type was made, and to describe each of them by a simple formula. But it would be necessary to make flaking diagrams of typical specimens only, and to draw the specimens with great care and accuracy.

It would be necessary to adopt the method of co-operative research in this matter* as no one man would be able to do all that is required. If one prehistorian would undertake to prepare flaking diagrams of a large number of ovates of the Chelles period, another the pointed implements of the same epoch, and so on, the work

* This idea has already been suggested and explained by Prof. Alfred Barnes, Proc. P.S.E.A., Vol. I., Part 4, pp. 449-454. 
would be accomplished and a great advance made. We should then be able to know exactly how any particular implement was made and to compare it with those found in other localities, and presumed to be of palæolithic date. It might of course turn out that no definite plan was followed in making flint implements, but the author does not consider this a likely contingency. But it must be remembered that even if it were ascertained definitely how any palæolithic implement was made, and that those found in superficial floors and on the present land surface showed an identical method of manufacture, it would still be open for those who wished to do so, to assert that neolithic man not only made palæolith-like implements, but followed exactly the same plan of manufacture as his ancestors. The attempt to settle the question on these lines ought, however, to be made, and in the author's opinion it is regrettable that the work has not already been commenced.

Another question which is coming into prominence is that of the alleged occurrence of palæolithic implements in the north of England, and in Scotland.

The Rev. Fredk. Smith of Queensferry, near Edinburgh, has for some years past held that he has found palæolithic implements in his own and other districts (see "The Stone Ages in North Britain and Ireland"). These specimens are not made from flint, but from various local rocks, and here again it seems to the author that a careful investigation ought to be made with a view to ascertain how these rocks fracture under various conditions. It is not sufficient to " believe" that palæolithic man never reached Scotland (we know the mammoth is found there and where this creature went man was probably able to go too). The whole question which has been discussed by Mr. Smith with ability and fulness, wants handling by careful and really scientific investigators anxious only that the truth shall be established. And the same applies to the alleged discoveries of palæolithic implements in Ireland.

There is no doubt that Great Britain affords quite a unique field for investigations and for advancing our knowledge of the ancient races of mankind. But in the author's opinion the whole subject needs handling in a more stringently scientific manner. The prehistorian must be able to discriminate infallibly between fact and theory, and never under any circumstances to confuse the two. He must learn also to describe his discoveries in terse and simple language, such as all may readily understand, and upon which only one possible interpretation can be put. Lastly, he must realise the very great responsibility which he assumes when announcing any new discovery, and be prepared always to view the question from the other man's standpoint. If all of us adhere rigidly to these principles, and are never afraid to acknowledge we are in the wrong, if such should be shown to be the case, there is a very bright prospect before the science of prehistorical research in this country. But at present the position of this science-is by no means satisfactory. 